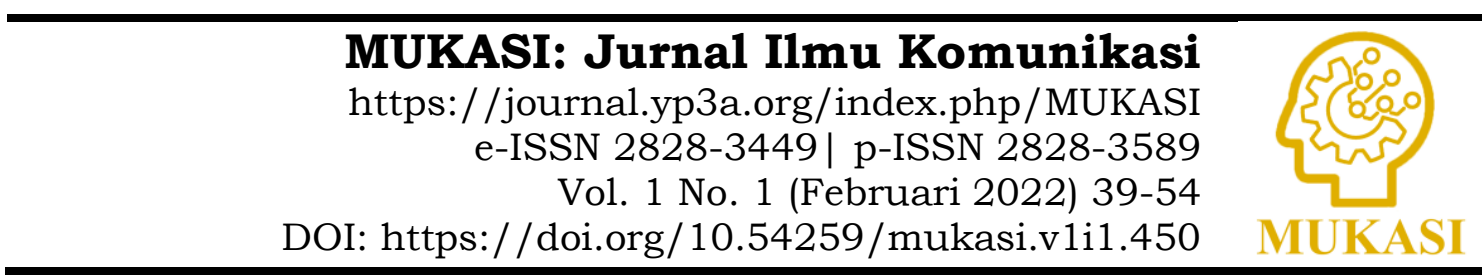

\title{
Kohesivitas Kelompok pada Koperasi di Kabupaten Tapanuli Utara
}

\author{
Juliana Nababan \\ Magister Ilmu Komunikasi, Fakultas Ilmu Sosial dan Ilmu Politik, \\ Universitas Sumatera Utara, Medan, Sumatera Utara, Indonesia \\ juliananababan@gmail.com
}

\begin{abstract}
In Indonesia, cooperatives are used as development agents for poverty alleviation by improving the welfare of people who have limited economic capacity through groups, for that cooperatives must continue to be fostered and developed so that they can continue to grow and develop both in quantity and quality. However, based on data on the number of cooperative units released by Badan Pusat Statistik Provinsi Sumatera Utara on February 26, 2021, Sumatera Utara decrease in the number of cooperatives. Many studies related to cooperatives have been carried out, starting from how the development of cooperatives in Indonesia, the role of cooperatives in improving community welfare, the effectiveness of cooperatives in developing a people's economy, the role of companions in the development of cooperatives and so on. However, there is still little research that examines how a cooperative can succeed and thrive, become dormant or even disband. This research aims to analyze relationship between individual characteristics and group cohesiveness in cooperatives. Group cohesiveness is an important aspect in achieving group goals because it is a determinant for the group's sustainability. The research use the theory of group communication and group cohesiveness. A quantitative correlational method is employed using the entire population (total sampling technique), namely all members of the three cooperatives located in North Tapanuli Regency. The data are collected through questionnaires and documentation with an ordinal scale on individual characteristics and group cohesiveness. The analysis results of correlation between variables, using the Spearman Rho Rank correlation test, show that individual characteristics have a significant correlation with the group cohesiveness. The individual characteristics possessed by cooperative members will reflect their personality which is manifested in the overall way the member interacts with other group members.
\end{abstract}

Keywords: Cooperatives, Group Cohesiveness, Quantitative Correlational, Individual Characteristics.

\begin{abstract}
ABSTRAK
Di Indonesia, koperasi dijadikan sebagai agen pembangunan untuk pengentasan kemiskinan dengan meningkatkan kesejahteraan masyarakat yang memiliki kemampuan ekonomi terbatas melalui kelompok, untuk itu koperasi harus terus dibina dan dikembangkan agar dapat terus tumbuh dan berkembang baik secara kuantitas maupun secara kualitas. Namun, berdasarkan data banyaknya unit koperasi yang dirilis oleh Badan Pusat Statistik Provinsi Sumatera Utara pada tanggal 26 Februari 2021, Sumatera Utara mengalami penurunan jumlah koperasi. Penelitian-penelitian terkait koperasi
\end{abstract}


telah banyak dilakukan, mulai dari bagaimana perkembangan koperasi di Indonesia, peran koperasi dalam meningkatkan kesejahteraan masyarakat, efektivitas koperasi dalam membangun ekonomi kerakyatan, peran pendamping dalam pengembangan koperasi dan lain sebagainya. Namun masih sedikit penelitian yang mengkaji bagaimana sebuah koperasi dapat berhasil dan berkembang, tidak aktif atau bahkan bubar. Penelitian ini bertujuan untuk menganalisis hubungan antara karakteristik individu dengan kohesivitas kelompok dalam koperasi. Kohesivitas kelompok merupakan salah satu aspek penting dalam mencapai tujuan kelompok karena menjadi penentu bagi keberlangsungan kelompok. Teori yang digunakan adalah komunikasi kelompok dan kohesivitas kelompok. Metode penelitian yang digunakan adalah metode kuantitatif korelasional dengan menggunakan teknik total sampling yaitu seluruh anggota pada tiga koperasi yang berada di Kabupaten Tapanuli Utara. Pengumpulan data menggunakan kuesioner dan dokumentasi dengan skala ordinal pada karakteristik individu dan kohesivitas kelompok. Hasil analisis hubungan antar variabel menggunakan uji korelasi Rank Spearman Rho menunjukkan bahwa karakteristik individu memiliki hubungan yang signifikan dengan kohesivitas kelompok. Karakteristik individu yang dimiliki oleh anggota koperasi akan mencerminkan kepribadiannya yang terwujud ke dalam keseluruhan cara anggota tersebut dalam berinteraksi dengan anggota kelompok lainnya.

Kata Kunci: Koperasi, Kohesivitas Kelompok, Kuantitatif Korelasional, Karakteristi Individu.

\section{PENDAHULUAN}

Manusia pada dasarnya merupakan makhluk sosial yang memerlukan komunikasi untuk dapat berinteraksi atau menjalin hubungan dengan sesama manusia dalam memenuhi kebutuhan hidupnya. Interaksi sosial antarmanusia tidak hanya bertujuan agar dapat hidup saja tetapi untuk saling bertukar informasi, pengetahuan, ide atau pemikiran, dan memuaskan serta menenangkan batin atau perasaan. Interaksi yang dilakukan, bisa untuk tujuan tertentu, namun bisa juga tidak mempunyai kepentingan khusus. Setiap hari, tanpa disadari kita berinteraksi dengan individu lain, melalui berbagai bentuk, kebutuhan dan kepentingan. Kita menjalin relasi dengan banyak orang, baik yang kita kenal secara dekat, sekedar kenal maupun orang yang baru kita kenal karena dikenalkan oleh teman kita.

Interaksi yang intensif dari sekumpulan individu yang saling mengenal dan mempunyai tujuan yang sama membentuk kelompok atau komunitas untuk memudahkan dalam mencapai tujuan individu maupun tujuan bersama. Menurut beberapa definisi tentang kelompok, dinyatakan bahwa sebuah kelompok setidaknya harus terdiri dari tiga atau lebih individu yang berinteraksi satu sama lain untuk mencapai tujuan tertentu, dimana interaksi biasanya dilakukan secara tatap muka, misalnya keluarga, kelompok belajar, kelompok kerja dan lain sebagainya.

Komunikasi merupakan bagian yang sangat penting dalam suatu kelompok, karena komunikasi tidak hanya sebagai instrumen atau alat untuk berinteraksi tetapi komunikasi adalah medium yang menyebabkan adanya kelompok atau organisasi, (Morissan, 2020). Proses komunikasi yang terjadi di dalam kelompok yang telah terbentuk menghasilkan berbagai hal seperti hubungan kewenangan yang bersifat formal, terciptanya peran, adanya jaringan komunikasi dan iklim organisasi. Kelompok juga dapat menciptakan hasil atau mencapai tujuan akibat adanya komunikasi di antara individu dan kelompok, yang pada gilirannya akan mempengaruhi interaksi masa depan di dalam kelompok.

Koperasi pada dasarnya merupakan kelompok atau organisasi sosial ekonomi yang dibentuk dengan tujuan untuk meningkatkan taraf hidup dan kesejahteraan setiap 
anggotanya hingga masyarakat disekitarnya. Koperasi juga berperan sebagai wadah kerjasama, sumber informasi dan pelayanan permodalan serta sebagai fasilitator dalam menjalin kerjasama dengan pihak lain yang dapat menunjang pengembangan usaha setiap anggotanya. Pendirian, pengelolaan dan pengawasan koperasi diatur dalam Undang-Undang Republik Indonesia Nomor 17 Tahun 2012 tentang Perkoperasian yang merupakan pengganti dari Undang-Undang Nomor 25 Tahun 1992, dengan tujuan agar pengelolaan dan pengembangan koperasi lebih terarah.

Berbagai jenis koperasi terbentuk seiring dengan beragamnya jenis usaha yang dikembangkan untuk meningkatkan kesejahteraan masyarakat, secara garis besar koperasi dapat dikategorikan menjadi lima jenis yaitu koperasi konsumen, koperasi produsen, koperasi jasa, koperasi simpan pinjam dan koperasi serba usaha. Di Indonesia, koperasi dijadikan sebagai agen pembangunan untuk pengentasan kemiskinan dengan meningkatkan kesejahteraan masyarakat melalui kelompok, (Sukidjo, 2008), untuk itu koperasi harus terus dibina dan dikembangkan agar dapat terus tumbuh dan berkembang baik secara kuantitas maupun secara kualitas. Konsep pemberdayaan masyarakat dalam bentuk kelompok seperti koperasi sering digunakan dan dikembangkan untuk menanggulangi permasalahan kemiskinan yang terjadi. Pentingnya pemberdayaan masyarakat berasal dari fakta bahwa hal ini sering dilihat sebagai solusi untuk masalah keterbelakangan ekonomi dan kemiskinan yang meluas.

Koperasi mempunyai peranan yang cukup besar dalam menyusun usaha bersama bagi masyarakat yang memiliki kemampuan ekonomi terbatas, (Sitepu dan Hasyim, 2018). Oleh karena itu, pengembangan koperasi digerakkan melalui dukungan program pemerintah untuk memajukan pertumbuhan dan perkembangan koperasi agar dapat menjalankan peranannya secara efektif. Berdasarkan data banyaknya unit koperasi yang dirilis oleh Badan Pusat Statistik Provinsi Sumatera Utara pada tanggal 26 Februari 2021 dalam katalog Provinsi Sumatera Utara dalam Angka 2021, dari 33 kabupaten/kota yang berada di Provinsi Sumatera Utara, 26 kabupaten/kota mengalami kenaikan jumlah koperasi pada tahun 2019, sedangkan 2 kota (Kota Sibolga dan Kota Binjai) tidak bertambah dan 5 kabupaten/kota mengalami penurunan jumlah koperasi yaitu Kabupaten Samosir, Kabupaten Pakpak Barat, Kabupaten Tapanuli Utara, Kabupaten Langkat, dan Kota Tanjungbalai.

Penelitian-penelitian terkait koperasi telah banyak dilakukan, mulai dari bagaimana perkembangan koperasi di Indonesia, peran koperasi dalam meningkatkan kesejahteraan masyarakat, efektivitas koperasi dalam membangun ekonomi kerakyatan, peran pendamping dalam pengembangan koperasi dan lain sebagainya. Hasil dari berbagai kajian juga memperlihatkan bahwa koperasi-koperasi yang terbentuk ada yang berhasil dan berkembang, tidak aktif atau bahkan bubar, seperti penelitian yang dilakukan oleh Tiurniari dan Heryenzus pada tahun 2017, dari 922 koperasi yang terdaftar secara resmi di Kota Batam, 526 koperasi (57\%) tidak aktif bahkan terancam akan dibubarkan, sehingga hanya 396 aktif dan salah satu yang menjadi permasalahannya berkaitan dengan komunikasi dan koordinasi antara dinas terkait dengan koperasi yang terbentuk. Selanjutnya, penelitian yang dilakukan oleh Fatimah dan Darna pada tahun 2011, dari 880 koperasi yang terdaftar di Dinas Koperasi Kota Depok, 590 koperasi tidak aktif dan faktor penyebabnya adalah rendahnya pemahaman anggota terhadap manfaat berkoperasi serta rendahnya kepercayaan anggota terhadap pengurus koperasi yang berdampak kepada keluarnya satu persatu anggota koperasi dari keanggotaannya. Selanjutnya, penelitian yang dilakukan Mangdalena dan Rudy pada tahun 2018, dari 525 koperasi yang tercatat di Kabupaten Bandung, 41 koperasi tidak aktif bahkan direkomendasikan oleh Dinas Koperasi untuk dibubarkan dan salah satu faktor penyebabnya adalah kurangnya partisipasi anggota dalam berkoperasi yang dapat 
diwujudkan dengan tertib membayar simpanan pokok, simpanan wajib dan simpanan sukarela serta bertransaksi dalam unit usaha koperasi.

Keberhasilan koperasi dalam mencapai tujuan yang ditetapkan tentu membutuhkan adanya kerjasama dari semua pihak yang terkait, mulai dari anggota dan pengelola koperasi, pendamping, lembaga swasta serta pemerintah. Kerjasama yang baik dapat mendorong pengembangan dan peningkatan produktivitas usaha setiap anggota, begitu juga sebaliknya, buruknya hubungan para stakeholder yang terkait dipastikan dapat menghambat pengembangan usaha dan pencapaian tujuan koperasi. Kerjasama dan pertukaran informasi dalam kelompok tidak terlepas dari proses komunikasi dan pola interaksi yang terjadi antaranggota dalam kelompok. Proses komunikasi dan pola interaksi ini dipengaruhi oleh kecenderungan anggota kelompok untuk berkomunikasi satu sama lain, karena tidak ada seorangpun yang berkomunikasi dengan cara yang sama terhadap seluruh anggota kelompok atau organisasi (Littlejohn \& Foss, 2013).

Kajian tentang kelompok tidak terlepas dari dasar terbentuknya suatu kelompok yaitu dibentuk dengan maksud dan tujuan untuk memenuhi kebutuhan setiap anggotanya, sehingga sangat penting untuk melihat bagaimana kelompok yang terbentuk dapat mencapai tujuan yang telah ditetapkan. Salah satu aspek penting dalam mencapai tujuan kelompok adalah kohesivitas kelompok, karena menjadi penentu bagi keberlangsungan kelompok. Menurut Mcshane dan Glinow, kohesivitas kelompok adalah perasaan daya tarik individu terhadap kelompok dan motivasi mereka untuk tetap bersama kelompok, dimana hal tersebut menjadi faktor yang penting dalam mencapai keberhasilan kelompok, (Cindoswari dan Junep, 2017). Proses komunikasi dan interaksi di dalam sebuah kelompok juga menentukan keeratan/kekompakan (kohesif) hubungan antara anggota kelompok.

\section{TINJAUAN PUSTAKA}

\section{Karakteristik Individu}

Individu merupakan sumber daya yang terpenting dalam suatu kelompok, orang-orang yang memberikan tenaga, ide, gagasan dan usaha kepada kelompok agar kelompok tetap eksis dan dapat mencapai tujuannya. Setiap individu memiliki ciri khas atau sifat khusus yang melekat pada diri individu dan menjadikan dirinya berbeda dengan individu lainnya, perbedaan ini sering disebut sebagai karakteristik individu. Newcomb et al. (Raharjo, 2016) mendefinisikan karakteristik individu sebagai ciri atau sifat yang dimiliki oleh individu yang ditampilkan melalui pola pikir, pola sikap dan pola tindak terhadap lingkungan hidup. Karakteristik individu sering dibedakan atas dasar umur, jenis kelamin, tingkat pendidikan, status sosial ekonomi, serta bangsa dan agama.

Terkait dengan kohesivitas kelompok, Fern menemukan bahwa karakteristik individu memiliki peranan yang penting dalam menentukan kohesivitas atau keeratan dan kolektivitas atau kesatupaduan dalam suatu kelompok, (Sidabutar, 2020). Fern berpendapat bahwa terdapat 4 (empat) karakteristik individu yang berperan penting dalam menentukan kohesivitas dan kolektivitas dalam suatu kelompok. Pertama, individu yang memiliki status sosial (tingkat pendidikan, tingkat pendapatan, pekerjaan dan kekayaan) yang lebih tinggi mempunyai kemampuan komunikasi yang lebih baik dan cenderung lebih patuh pada norma dalam kelompok dibandingkan dengan individu yang memiliki status sosial yang lebih rendah. Kedua, Umur, relasi sosial seseorang sudah terbentuk seiring dengan semakin dewasanya umur seseorang sehingga mampu mendorong kolektivitas dalam kelompok. Ketiga, Ras/etnis, perbedaan karakteristik ras/etnis dapat mempengaruhi kolektivitas suatu kelompok. Keempat, jenis kelamin, berdasarkan hasil beberapa penelitian, jenis kelamin dapat berpengaruh terhadap interaksi dan hasil dari diskusi kelompok. 
Berdasarkan pengertian karakteristik individu dari para ahli dan hasil-hasil kajian yang telah dikemukakan diatas dapat disimpulkan bahwa karakteristik individu adalah atribut yang membedakan setiap individu berdasarkan aspek demografis dan status sosial yang mempengaruhi interaksi dalam suatu kelompok. Adapun indikator karakteristik individu yang digunakan dalam penelitian ini adalah umur, pendididikan formal, pendidikan non formal, pengalaman usaha, masa keanggotaan, jumlah tanggungan, pendapatan dan kepemilikan media informasi.

\section{Kohesivitas Kelompok}

Komunikasi yang terjadi antara anggota kelompok dalam pelaksanaan setiap kegiatan atau dapat dikatakan kegiatan komunikasi kelompok, seperti rapat dan diskusi, dimana anggota kelompok tidak hanya saling berinteraksi tetapi mereka juga melibatkan perasaan mereka, (Homans dalam Mulyana, 2007). Kegiatan kelompok ini menuntut anggotanya untuk lebih sering berkumpul dan melakukan aktivitas secara bersamasama, sehingga komunikasi yang terjalin diantara anggota semakin intensif dan menjadi semakin terbuka, memiliki ikatan emosional, akrab dan solid. Hal inilah yang akan menciptakan rasa saling memiliki dan tertarik antara anggota kelompok atau kepaduan kelompok yang disebut dengan kohesivitas kelompok.

Collins dan Raven menyatakan bahwa kohesivitas merupakan kekuatan yang mendorong anggota kelompok untuk tetap tinggal di dalam kelompok dan mencegahnya untuk meninggalkan kelompok, (Rakhmat, 2018). Baron dan Byrne (2004) mendefinisikan kohesivitas sebagai seluruh kekuatan yang menyebabkan anggota untuk bertahan dalam suatu kelompok, seperti kesukaan terhadap anggota lain dalam kelompok dan keinginan untuk menjaga dan meningkatkan status dengan menjadi anggota dari kelompok yang tepat. Kohesivitas mencerminkan hubungan persahabatan dan menyukai orang lain serta kerjasama dan komunikasi yang positif, (Morisson, 2007). Menurut Mcshane dan Glinow, kohesivitas kelompok adalah perasaan daya tarik individu terhadap kelompok dan motivasi mereka untuk tetap bersama kelompok dimana hal tersebut menjadi faktor yang penting dalam mencapai keberhasilan kelompok, (Cindoswari dan Junep, 2017).

Kohesivitas kelompok merupakan dimensi yang fundamental dari struktur kelompok dan secara meyakinkan berpengaruh terhadap perilaku kelompok, (Walgito, 2003). Kelompok yang memiliki kohesivitas tinggi, berarti setiap anggota kelompok saling berinteraksi satu sama lain, termotivasi untuk tinggal dalam kelompok, saling bekerja sama dengan baik dan memiliki komitmen yang kuat untuk mencapai tujuan kelompok, dimana hal ini akan mempengaruhi keberlangsungan kelompok tersebut. Kelompok yang memiliki kohesivitas rendah atau tidak kompak, maka anggota-anggota kelompok akan saling tidak menyukai, sehingga menimbulkan ketidaknyamanan untuk berada dalam kelompok.

Pola komunikasi dapat dipahami sebagai pola hubungan antara dua orang atau lebih dalam pengiriman dan penerimaan pesan dengan cara yang tepat sehingga pesan yang dimaksud dapat dipahami, (Djamarah, 2004). Pola komunikasi ini memiliki hubungan yang erat dengan kohesivitas kelompok karena bentuk dan struktur aliran pesan atau informasi yang dipertukarkan antara peran-peran anggota di dalam kelompok menentukan efektivitas komunikasi dalam mencapai tujuan kelompok (Cindoswari dan Junep, 2017). Komunikasi yang efektif dengan pola komunikasi tertentu yang digunakan dalam pencapaian tujuan kelompok akan mendorong adanya keterikatan anggota kelompok dengan kelompoknya.

Berdasarkan penelitian yang dilakukan oleh Cindoswari dan Junep pada tahun 2017, hasil penelitiannya menunjukkan bahwa pola komunikasi pada kelompok etnis Sunda dan kohesivitas kelompok memiliki hubungan yang sangat erat. Struktur komunikasi 
dan pola komunikasi yang terbentuk dalam kelompok tersebut, menciptakan iklim keterbukaan dimana tingkat interaksi antar anggota kelompok meningkat. Peningkatan interaksi ini memperkuat ikatan kebersamaan antar anggota kelompok sehingga tercipta kohesivitas yang kuat. Selanjutnya, hasil penelitian Wahyuni et al. (2017) dan Siregar (2019) menunjukkan bahwa jaringan komunikasi pada kelompok tani yang diteliti memiliki hubungan yang nyata dengan dinamika kelompok, dimana kohesivitas kelompok merupakan salah satu unsur dari dinamika kelompok.

Menurut Forsyth terdapat empat dimensi kohesivitas kelompok yaitu sebagai berikut: Pertama, kekuatan sosial yaitu keseluruhan dari dorongan yang dilakukan oleh individu dalam kelompok untuk tetap berada dalam kelompoknya. Dorongan yang menjadikan anggota kelompok selalu berhubungan dan kumpulan dari dorongan tersebut membuat mereka bersatu. Kedua, kesatuan dalam kelompok yaitu perasaan saling memiliki terhadap kelompoknya dan memiliki perasaan moral yang berhubungan dengan keanggotaannya dalam kelompok. Setiap individu dalam kelompok merasa kelompok adalah sebuah keluarga, tim dan komunitasnya serta memiliki perasaan kebersamaan. Ketiga, daya tarik yaitu individu akan lebih tertarik melihat dari segi kelompok kerjanya sendiri daripada melihat dari anggotanya secara spesifik. Keempat, kerjasama kelompok yaitu individu memiliki keinginan yang lebih besar untuk berkerjasama untuk mencapai tujuan kelompok, (Utami, 2017).

Berdasarkan pengertian kohesivitas kelompok dari para ahli dan hasil-hasil kajian yang telah dikemukakan diatas dapat disimpulkan bahwa kohesivitas kelompok adalah kekuatan yang mendorong anggota untuk bertahan dalam suatu kelompok dan bekerja sama dalam mencapai tujuan kelompok. Adapun indikator kohesivitas kelompok yang digunakan dalam penelitian ini adalah kekuatan sosial, kesatuan dalam kelompok, daya tarik dan kerjasama kelompok. Penelitian ini dilakukan untuk mengkaji apakah terdapat hubungan antara karakteristik individu dengan kohesivitas kelompok yang terbentuk dalam koperasi.

\section{METODE}

Penelitian ini menggunakan metode penelitian kuantitatif korelasional, dimana hasil akhir dari penelitiannya adalah menguji hubungan antara variabel-variabel penelitian yang dihipotesiskan. Lokasi penelitian berada di Kabupaten Tapanuli Utara, dengan pertimbangan berdasarkan data BPS Provinsi Sumatera Utara tahun 2021, Kabupaten Tapanuli Utara merupakan salah satu dari lima kabupaten yang mengalami penurunan jumlah koperasi di Sumatera Utara. Berdasarkan data yang diperoleh dari BPS dan Dinas Koperasi, Usaha Kecil dan Menengah Kabupaten Tapanuli Utara, dari 486 koperasi yang tercatat, hanya 102 koperasi yang aktif dan tersebar di 14 dari 15 kecamatan yang berada di Kabupaten Tapanuli Utara. 37 dari 102 koperasi tersebut merupakan jenis koperasi serba usaha (KSU) yang merupakan fokus dari penelitian ini karena koperasi serba usaha mencakup semua kegiatan usaha dari empat jenis koperasi lainnya.

Subjek penelitian ada tiga koperasi yaitu KSU A, KSU B dan KSU C. KSU A berada di kecamatan Sipoholon, KSU B berada di kecamatan Siborongborong dan KSU C berada di kecamatan Pagaran. Pemilihan ketiga koperasi tersebut dilakukan berdasarkan data BPS Kabupaten Tapanuli Utara tahun 2021, 60.39 \% pekerja di Tapanuli Utara berada di sektor pertanian dan tiga kecamatan tersebut merupakan kecamatan yang masuk dalam kategori dengan tingkat kepadatan penduduk tinggi di Kabupaten Tapanuli Utara. Penelitian menggunakan total sampling atau metode sensus terhadap seluruh anggota setiap koperasi. Adapun jumlah anggota yang aktif pada KSU A berjumlah 24 orang, KSU C berjumlah 26 orang dan KSU B berjumlah 34 orang, sehingga total responden dalam penelitian ini adalah 84 responden. 
Uji validitas dilakukan melalui 4 (empat) langkah, yaitu: mendefinisikan secara operasional konsep yang akan diukur, melakukan uji coba skala pengukur tersebut pada sejumlah responden, mempersiapkan tabel tabulasi jawaban dan yang terakhir menghitung korelasi antara tiap-tiap pernyataan dan skor total dengan menggunakan rumus teknik korelasi product moment atau Ranks Spearman. Uji validitas pada penelitian ini akan dilakukan dengan menggunakan alat bantu aplikasi SPSS 26. Uji reliabilitas pada penelitian ini akan dilakukan dengan menggunakan reliabilitas koefisien cronbach alpha melalui alat bantu aplikasi SPSS 26. Semakin tinggi koefisien reliabilitas maka semakin reliable jawaban yang diperoleh dari responden

Pengumpulan data untuk memperoleh data mengenai karakteristik individu dilakukan dengan menggunakan pertanyaan tertutup dan terbuka untuk memperoleh informasi dari responden. Item pertanyaan dalam variabel karakteristik individu ini berjumlah 9 pertanyaan. Selanjutnya, pengumpulan data untuk memperoleh data mengenai kohesivitas kelompok dilakukan dengan menggunakan 40 pernyataan yang terdiri dari 28 pernyataan positif (favourable) dan 12 pernyataan negatif (unfavourable). Data setiap variabel yang telah dikumpulkan kemudian dianalis korelasinya menggunakan uji korelasi rank Spearman Rho dengan bantuan aplikasi SPSS 26.

\section{HASIL DAN PEMBAHASAN}

Karakteristik Individu

Karakteristik individu merupakan perbedaan ciri yang dimiliki oleh setiap individu yang dapat mencakup aspek demografis, keterampilan dan kemampuan yang dapat mempengaruhi interaksi dan hasil kerja dalam suatu kelompok. Karakteristik individu yang digunakan dalam penelitian ini adalah usia, tingkat pendidikan formal, pendidikan non formal, pengalaman bertani, masa keanggotaan dalam kelompok, jumlah tanggungan, pendapatan perbulan dan kepemilikan media informasi.

Tabel 1. Persentase anggota koperasi A, B dan C berdasarkan karakteristik individu

\begin{tabular}{c|c|c|c}
\hline \multirow{2}{*}{ Karakteristik Individu } & \multicolumn{3}{|c}{ Persentase } \\
\cline { 2 - 4 } & Koperasi A & Koperasi B & Koperasi C \\
\hline Usia & & & \\
20-39 tahun (Dewasa Awal) & 16,67 & 3,85 & 23,53 \\
40-65 tahun (Dewasa Tengah) & 70,83 & 80,77 & 73,53 \\
>65 tahun (Dewasa Akhir) & 12,50 & 15,38 & 2,94 \\
\hline Pendididikan formal & & & \\
Rendah & 4,17 & 11,54 & 11,77 \\
Sedang & 95,83 & 88,46 & 88,23 \\
Tinggi & 0,00 & 0,00 & 0,00 \\
\hline & & & \\
Pendidikan non formal & & & \\
Rendah & 62,50 & 73,08 & 73,53 \\
Sedang & 37,50 & 26,92 & 26,47 \\
Tinggi & 0,00 & 0,00 & 0,00 \\
\hline Rendah & \multicolumn{3}{|}{} \\
Sedang & 4,17 & 0,00 & 11,77 \\
Tinggi & 58,33 & 53,85 & 38,23 \\
& 37,50 & 46,15 & 50,00 \\
\hline Pengalaman usaha
\end{tabular}

Masa keanggotaan 


\begin{tabular}{rccc}
\hline Rendah & 25,00 & 7,69 & 8,82 \\
Sedang & 75,00 & 19,23 & 26,47 \\
Tinggi & 0,00 & 73,08 & 64,71 \\
\hline Jumlah tanggungan & & & \\
Rendah & 62,50 & 69,23 & 35,30 \\
Sedang & 20,83 & 23,08 & 29,41 \\
Tinggi & 16,67 & 7,69 & 35,29 \\
\hline Pendapatan & & & \\
Sedang & 0,00 & 0,00 & 0,00 \\
Tinggi & 16,67 & 0,00 & 5,88 \\
Repemilikan media informasi & 83,33 & 100,00 & 94,12 \\
Rendah & & & \\
Sedang & 54,17 & 76,92 & 85,29 \\
Tinggi & 45,83 & 23,08 & 14,71 \\
& 0,00 & 0,00 & 0,00 \\
\hline
\end{tabular}

(Sumber: Hasil olahan peneliti, 2021)

Data karakteristik individu pada tabel 1 menunjukkan bahwa kategori usia dewasa tengah yakni 40 hingga 65 tahun memiliki persentase yang tinggi pada ketiga koperasi, sedangkan dewasa awal (generasi muda) masih jarang yang bergabung dengan koperasi. Karakteristik selanjutnya yaitu pendidikan formal, ketiga koperasi tergolong pada tingkat pendidikan kategori sedang yakni mayoritas anggota koperasi telah menamatkan pendidikan Sekolah Menengah Pertama (SMP) hingga Sekolah Menengah Atas (SMA) atau sederajat, akan tetapi pada tingkat pendidikan non formal ketiga koperasi yang menjadi subjek penelitian ini mayoritas masuk dalam kategori rendah. Hal ini menunjukkan bahwa ketiga koperasi tidak banyak menerima pelatihan baik pelatihan manajemen koperasi dari Dinas Koperasi UKM maupun pelatihan tentang produksi pertanian dari Dinas Pertanian ataupun pihak lainnya.

Selanjutnya, pengalaman usaha tani anggota pada koperasi $\mathrm{C}$ mayoritas tergolong pada kategori tinggi, yakni diatas 25 tahun, sementara sebagian besar anggota koperasi A dan B masuk ke dalam kategori sedang dengan pengalaman usaha dalam bidang pertanian 10 hingga 25 tahun. Hal ini dikarenakan sebagian besar anggota koperasi menjadikan usaha tani sebagai mata pencaharian utama setelah menamatkan pendidikan formalnya. Selanjutnya, masa keanggotaan pada koperasi A masuk dalam kategori sedang, berbeda dengan dua koperasi lainnya yakni koperasi $\mathrm{B}$ dan $\mathrm{C}$ yang tergolong pada kategori tinggi. Hal ini dikarenakan koperasi $\mathrm{B}$ dan $\mathrm{C}$ terbentuk lebih dahulu dibandingkan koperasi A.

Karakteristik selanjutnya yang dianalisis dalam penelitian ini adalah jumlah tanggungan anggota koperasi. Jika dilihat dari jumlah jiwa yang menjadi tanggungan anggota koperasi, mayoritas anggota koperasi A dan B masuk dalam kategori rendah, sementara koperasi C dari 34 orang anggota sebanyak 35,294 persen masuk dalam kategori rendah yakni memiliki tanggungan di bawah 3 orang, 29,412 persen masuk dalam kategori sedang dan sisanya yaitu sebanyak 35,294 persen tergolong kategori tinggi dengan jumlah tanggungan lebih dari 3 orang.

Karakteristik selanjutnya adalah pendapatan perbulan responden ditambah dengan suami atau istrinya, dari tabel 4.2 terlihat bahwa pendapatan mayoritas anggota dari ketiga koperasi masuk dalam kategori pendapatan tinggi dengan pendapatan rata-rata perbulan Rp 3.000.000,- ke atas yaitu sebanyak 83,33 persen dari total anggota koperasi 
A, 94,12 persen anggota koperasi C dan seluruh anggota koperasi B tergolong memiliki pendapatan yang tinggi. Selanjutnya, jika dilihat dari jumlah media informasi dan komunikasi yang dimiliki oleh responden, umumnya anggota koperasi masuk dalam kategori rendah dimana rata-rata anggota hanya memiliki televisi dan telepon selular sementara anggota lainnya masuk dalam kategori sedang. Tidak satupun anggota koperasi yang masuk dalam kategori tinggi.

\section{Kohesivitas Kelompok}

Kohesivitas kelompok merupakan perasaan daya tarik individu yang mendorongnya untuk tetap tinggal bersama di dalam kelompok dan mencegahnya untuk meninggalkan kelompok, dimana hal ini menjadi faktor penting yang mempengaruhi keberlangsungan dan pencapaian tujuan kelompok. Kelompok yang memiliki kohesivitas tinggi, berarti setiap anggota kelompok saling berinteraksi satu sama lain, termotivasi untuk tinggal dalam kelompok, saling bekerja sama dengan baik dan memiliki komitmen yang kuat untuk mencapai tujuan kelompok. Kelompok yang memiliki kohesivitas rendah atau tidak kompak, maka anggota-anggota kelompok akan saling tidak menyukai, sehingga menimbulkan ketidaknyamanan untuk berada dalam kelompok. Pengukuran kohesivitas kelompok dilakukan melalui empat indikator yaitu kekuatan sosial, kesatuan dalam kelompok, daya tarik dan kerjasama kelompok.

Pengukuran tingkat kohesivitas kelompok untuk setiap indikator dalam kuesioner menggunakan pernyataan positif (favourable) dan pernyataan negatif (unfavourable). Pernyataan positif merupakan pernyataan yang mendukung kohesivitas kelompok, sebaliknya pernyataan yang negatif merupakan pernyataan yang tidak mendukung kohesivitas kelompok.

Berdasarkan hasil olahan data yang telah dilakukan, secara keseluruhan ketiga koperasi yang menjadi subjek penelitian memiliki kohesivitas yang masuk ke dalam kategori tinggi dan dari keempat indikator kohesivitas kelompok pada ketiga koperasi, tidak ada responden yang masuk ke dalam kategori rendah.

Tabel 2. Persentase anggota koperasi A, B dan C berdasarkan kohesivitas kelompok

\begin{tabular}{l|c|c|c|c}
\hline \multirow{2}{*}{$\begin{array}{c}\text { Indikator } \\
\text { Kohesivitas } \\
\text { Kelompok }\end{array}$} & Kategori & \multicolumn{3}{|c}{ Persentase } \\
\cline { 3 - 5 } & & Koperasi A & Koperasi B & Koperasi C \\
\hline Kekuatan sosial & Rendah & 0 & 0 & 0 \\
& Sedang & 29,17 & 19,23 & 38,24 \\
& Tinggi & 70,83 & 80,77 & 61,76 \\
\hline Kesatuan dalam & Rendah & 0 & 0 & 0 \\
kelompok & Sedang & 29,17 & 34,61 & 47,06 \\
& Tinggi & 70,83 & 65,39 & 52,94 \\
\hline Kerjasama & Rendah & 0 & 0 & 0 \\
kelompok & Sedang & 33,33 & 26,92 & 35,29 \\
& Tinggi & 66,67 & 73,08 & 64,71 \\
\hline Daya tarik & Rendah & 0 & 0 & 0 \\
& Sedang & 29,17 & 34,61 & 44,12 \\
& Tinggi & 70,83 & 65,39 & 55,88 \\
\hline
\end{tabular}

(Sumber: Hasil olahan peneliti, 2021) 
Indikator kekuatan sosial pada ketiga koperasi seperti yang terlihat pada tabel 2, menunjukkan sebagian besar anggota koperasi menyatakan bahwa mereka senang bergabung dengan koperasi. Seperti pada koperasi A, 70,83 persen anggota koperasi menyatakan selalu terdorong untuk bekerjasama dengan anggota koperasi lainnya karena mereka merasa diterima sebagai keluarga dan mendapatkan pengetahuan serta pengalaman yang baru setelah bergabung dengan koperasi. Hal ini tidak jauh berbeda dengan dua koperasi lainnya yakni 80,77 persen anggota koperasi B dan 61,76 persen anggota koperasi $\mathrm{C}$ selalu merasa senang dapat berkontribusi dengan baik bagi koperasi yang diikutinya. Sementara, anggota koperasi yang berada pada kategori sedang, kurang dapat berkontribusi dan bekerjasama dalam setiap kegiatan kelompok dikarenakan adanya pekerjaan lain diluar bidang pertanian seperti menjahit, tukang bangunan dan lain sebagainya.

Selanjutnya, indikator kesatuan dalam kelompok, yaitu rasa kebersamaan dan saling memiliki terhadap kelompok. Berdasarkan tabel 2, 70,83 persen anggota koperasi A menyukai kekompakan yang terbangun dalam koperasi dan berusaha memberikan ideide terbaiknya demi kemajuan kelompok. Hal yang sama juga terjadi pada dua koperasi lainnya yaitu 65,39 dari anggota koperasi B dan 52,94 anggota koperasi C merasakan adanya kebersamaan, saling memberikan semangat serta saling menghargai pendapat anggota lainnya. Sementara, anggota lain yang berada pada kategori sedang, merasa bahwa tidak semua anggota diperlakukan sama dalam koperasi.

Indikator selanjutnya, kerjasama kelompok yaitu keinginan yang dimiliki individu untuk bekerjasama dalam mencapai tujuan kelompok. Berdasarkan tabel 2, sebanyak 66,67 persen anggota koperasi A memiliki keinginan yang besar untuk bekerjasama dengan setiap anggota koperasi lainnya untuk mempercepat dan mempermudah penyelesaian setiap pekerjaan serta selalu siap sedia membantu anggota lain dalam menjalankan tugasnya. Hal yang sama juga terjadi pada dua koperasi lainnya, dimana 73,08 persen anggota koperasi B dan 64,71 persen anggota koperasi C selalu mengutamakan kegiatan yang dilaksanakan koperasi dan menyelesaikan tugas yang diberikan. Sementara, anggota lain yang berada pada kategori sedang, belum dapat membantu setiap anggota lainnya ataupun mengikuti setiap kegiatan koperasi dikarenakan adanya pekerjaan lain. Daya tarik sebagai indikator keempat dari variabel kohesivitas kelompok yaitu ketertarikan individu untuk menilai atau melihat dari segi kelompok. Berdasarkan tabel 4.3, lebih dari setengah anggota koperasi A tepatnya 70,83 persen menyatakan bahwa koperasi yang diikutinya dapat diandalkan dalam menyelesaikan berbagai masalah yang dihadapi serta merasa nyaman dan senang ketika diajak bekerjasama dengan anggota lainnya. Hal yang sama juga terjadi pada dua koperasi lainnya, dimana 65,39 persen anggota koperasi B dan 55,88 persen anggota koperasi C percaya akan kemampuan rekannya dalam menjalankan tugas yang diberikan. Sementara, anggota lain yang berada pada kategori sedang, merasa cukup keberatan jika diberikan tugas karena memiliki pekerjaan lain yang dijadikan sebagai sumber mata pencaharian.

\section{Diskusi}

Individu merupakan sumber daya yang sangat penting dalam suatu kelompok, orangorang yang memberikan tenaga, ide, gagasan dan usaha kepada kelompok agar kelompok tetap eksis dan dapat mencapai tujuannya. Setiap individu memiliki ciri khas atau sifat khusus yang melekat pada diri individu dan menjadikannya berbeda dengan individu lainnya, perbedaan ini sering disebut sebagai karakteristik individu. Karakteristik individu merupakan perbedaan ciri yang dimiliki oleh setiap individu yang dapat mencakup aspek demografis (usia, jenis kelamin, pendidikan atau pekerjaan), keterampilan dan kemampuan yang dapat mempengaruhi interaksi dan hasil kerja dalam suatu kelompok. Terkait dengan kohesivitas kelompok, Fern menemukan bahwa 
karakteristik individu memiliki peranan yang penting dalam menentukan kohesivitas atau keeratan dan kolektivitas atau kesatupaduan dalam suatu kelompok, (Sidabutar, 2020).

Analisis korelasi antara variabel karakteristik individu dengan variabel kohesivitas kelompok dilakukan dengan uji korelasi rank Spearman Rho karena data yang diperoleh dari kedua variabel dalam bentuk ordinal. Variabel karakteristik individu yang diuji adalah usia, pendidikan formal, pendidikan non formal, pengalaman usaha, masa keanggotaan, jumlah tanggungan, pendapatan dan kepemilikan media informasi, sementara variabel kohesivitas kelompok yang diuji adalah kekuatan sosial, kesatuan dalam kelompok, daya tarik dan kerjasama kelompok.

Hasil penelitian menunjukkan bahwa karakteristik individu memiliki hubungan yang signifikan dan positif dengan kohesivitas kelompok. Hasil ini membuktikan bahwa hipotesis dalam penelitian ini yang menyatakan bahwa karakteristik individu memiliki hubungan yang signifikan dengan kohesivitas kelompok dapat diterima. Artinya, karakteristik individu yang dimiliki oleh setiap anggota koperasi memiliki hubungan yang signifikan terhadap dorongan atau komitmen anggota untuk tetap bergabung dengan koperasi, meningkatnya rasa kekeluargaan atau kebersamaan, meningkatnya keinginan untuk bekerjasama dan kecenderungan untuk menjadikan koperasi yang diikutinya sebagai kelompok acuan. Kelompok acuan adalah kelompok yang menjadi acuan seseorang untuk bersikap, menilai atau bertindak.

Hasil ini sesuai dengan penelitian yang dilakukan oleh Bakti pada tahun 2017, bahwa karakteristik individu merupakan salah satu faktor penting dalam proses pembentukan kohesivitas pada kelompok tani yang diteliti. Hal ini dikarenakan karakteristik individu yang dimiliki oleh anggota kelompok akan mencerminkan kepribadiannya yang terwujud ke dalam keseluruhan cara anggota tersebut dalam berinteraksi dengan anggota kelompok lainnya. Kepribadian yang dimaksud adalah sebagai keseluruhan cara bagaimana individu bereaksi dan berinteraksi dengan orang lain (Kurniawati, 2007).

Forsyth mengemukakan empat dimensi penting dari kohesivitas kelompok yaitu kekuatan sosial, kesatuan dalam kelompok, kerjasama kelompok dan daya tarik, (Utami, 2017). Hasil penelitian menunjukkan bahwa kohesivitas kelompok pada ketiga koperasi yang menjadi subjek penelitian tergolong tinggi. Pertama, kekuatan sosial yaitu kekuatan yang mendorong individu untuk bertahan atau tetap tinggal dalam suatu kelompok dan mencegahnya untuk meninggalkan kelompok. Seperti yang terlihat pada ketiga koperasi, mayoritas anggotanya menyatakan merasa diterima sebagai keluarga dan mendapatkan pengetahuan serta pengalaman yang baru setelah bergabung dengan koperasi sehingga tujuannya untuk bergabung dengan koperasi tercapai.

Kedua, kesatuan dalam kelompok yaitu perasaan saling memiliki terhadap kelompoknya, dimana setiap anggota dalam kelompok merasa kelompoknya adalah keluarga, tim dan komunitasnya serta memiliki rasa kebersamaan antaranggota kelompok. Hal ini terlihat dari hasil analisis data pada ketiga koperasi, dimana sebagian besar anggota koperasi merasakan adanya kebersamaan, saling memberikan semangat serta saling menghargai satu sama lain sehingga anggota kelompok selalu berusaha memberikan ide-ide terbaiknya demi kemajuan kelompok.

Ketiga, kerjasama kelompok yaitu anggota kelompok memiliki keinginan yang lebih besar untuk bekerjasama dalam mencapai tujuan kelompok. Hal ini dapat terlihat pada ketiga koperasi, dimana hasil analisis data yang telah dilakukan menunjukkan bahwa mayoritas anggota memiliki keinginan yang besar untuk berkerjasama dengan anggota koperasi lainnya guna mempercepat penyelesaian setiap pekerjaan dan selalu bersedia untuk membantu anggota lain dalam menjalankan tugasnya. Anggota koperasi juga 
selalu mengutamakan kegiatan yang dilaksanakan koperasi dan menyelesaikan tugas yang diberikan.

Keempat, daya tarik yaitu anggota koperasi lebih tertarik melihat dari segi kelompok kerjanya daripada melihat dari anggotanya secara spesifik. Anggota koperasi memiliki kecenderungan untuk menjadikan koperasi yang diikutinya sebagai kelompok acuan. Kelompok acuan adalah kelompok yang menjadi acuan seseorang untuk bersikap, menilai atau bertindak. Hal ini tercermin pada ketiga koperasi, dimana hasil analisis data menunjukkan bahwa sebagian besar anggota koperasi merasa koperasi yang diikutinya dapat diandalkan dalam menyelesaikan berbagai masalah yang dihadapi dan percaya akan kemampuan rekannya dalam menjalankan tugas yang diberikan.

Analisis tabulasi silang dan uji korelasi rank Spearman Rho dilakukan untuk melihat secara rinci indikator variabel karakteristik individu mana saja yang memiliki hubungan yang signifikan dengan indikator variabel kohesivitas kelompok. Hasil hubungan antar indikator variabel yang diperoleh pada ketiga koperasi bervariasi. Pertama, pada koperasi A, tingkat pendidikan non formal memiliki hubungan yang signifikan dan positif dengan kekuatan sosial. Artinya, semakin sering anggota koperasi mengikuti berbagai pelatihan baik yang terkait dengan organisasi maupun pertanian, maka semakin tinggi juga komitmennya untuk bertahan atau tetap tinggal dalam koperasi. Selanjutnya, karakteristik individu yang memiliki hubungan yang positif dan signifikan dengan kesatuan dalam kelompok adalah jumlah tanggungan. Artinya, semakin tinggi atau banyak anggota keluarga yang menjadi tanggungan anggota koperasi maka semakin tinggi rasa saling memiliki dan rasa kebersamaan diantara anggota koperasi. Lebih lanjut, karakteristik individu yang memiliki hubungan yang positif dan signifikan dengan kerjasama dan daya tarik kelompok adalah tingkat pendidikan non formal dan pengalaman bertani anggota koperasi. Artinya, semakin sering anggota koperasi mengikuti berbagai pelatihan dan semakin tinggi pengalamannya di bidang pertanian, maka dorongan atau keinginan untuk bekerjasama dengan anggota lain semakin besar dalam rangka mencapai tujuan koperasi, serta semakin besar juga kecenderungan anggota untuk menjadikan koperasi yang diikutinya sebagai kelompok acuan.

Kedua, pada koperasi C, karakteristik individu yang memiliki hubungan yang positif dan signifikan dengan kekuatan sosial adalah tingkat pendidikan non formal dan pengamalan bertani. Artinya, semakin sering anggota koperasi mengikuti berbagai pelatihan dan semakin tinggi pengalamannya di bidang pertanian, maka semakin tinggi juga komitmennya untuk bertahan dan mencegahnya meninggalkan koperasi. Selanjutnya, karakteristik individu yang memiliki hubungan yang positif dan signifikan dengan kesatuan dalam kelompok adalah usia, pendidikan non formal dan pengalaman usaha. Artinya, semakin tua anggota dan semakin sering mengikuti berbagai pelatihan serta semakin tinggi pengalaman bertaninya, maka semakin tinggi rasa saling memiliki dan rasa kebersamaan diantara anggota koperasi. Lebih lanjut, karakteristik individu yang memiliki hubungan yang positif dan signifikan dengan kerjasama dan daya tarik kelompok adalah usia, pendidikan non formal dan pengalaman bertani. Artinya, semakin tua anggota dan semakin sering mengikuti berbagai pelatihan serta semakin tinggi pengalaman bertaninya, maka dorongan atau keinginan untuk bekerjasama dengan anggota lain semakin besar dalam rangka mencapai tujuan koperasi, serta semakin besar juga kecenderungan anggota untuk menjadikan koperasi yang diikutinya sebagai kelompok acuan.

Ketiga, pada koperasi B, karakteristik individu yang memiliki hubungan yang positif dan signifikan dengan kekuatan sosial adalah usia, tingkat pendidikan non formal dan masa keanggotaan. Artinya, semakin tua anggota koperasi dan semakin tinggi pendidikan non formal serta semakin lama menjadi anggota koperasi, maka semakin tinggi juga komitmennya untuk bertahan dan mencegahnya meninggalkan koperasi. 
Lebih lanjut, karakteristik individu yang memiliki hubungan yang positif dan signifikan dengan kesatuan dalam kelompok adalah usia dan masa keanggotaannya, yang artinya semakin tua dan semakin lama anggota bergabung dengan koperasi maka semakin meningkat juga rasa kebersamaan antaranggota koperasi. Selanjutnya, karakteristik individu yang memiliki hubungan yang positif dan signifikan dengan daya tarik kelompok adalah usia, pendidikan non formal dan masa keanggotaan. Artinya, semakin tua anggota koperasi dan semakin tinggi pendidikan non formal serta semakin lama bergabung dengan koperasi, maka semakin tinggi juga kecenderungan anggota untuk menjadikan koperasi yang diikutinya sebagai kelompok acuan dalam bersikap, menilai dan bertindak.

Tabel 3. Hasil Uji Korelasi Karakteristik Individu dengan Kohesivitas Kelompok

\begin{tabular}{|c|c|c|c|c|}
\hline \multicolumn{3}{|c|}{ Koperasi A } & $\begin{array}{c}\text { Karakteristik } \\
\text { Individu }\end{array}$ & $\begin{array}{l}\text { Kohesivitas } \\
\text { Kelompok }\end{array}$ \\
\hline \multirow{6}{*}{$\begin{array}{l}\text { Spearman's } \\
\text { rho }\end{array}$} & \multirow{3}{*}{$\begin{array}{l}\text { Karakteristik } \\
\text { Individu }\end{array}$} & Correlation Coefficient & 1,000 & $.779^{* *}$ \\
\hline & & Sig. (2-tailed) & & 0,000 \\
\hline & & $\mathrm{N}$ & 24 & 24 \\
\hline & \multirow{3}{*}{$\begin{array}{l}\text { Kohesivitas } \\
\text { Kelompok }\end{array}$} & Correlation Coefficient & $.779^{* *}$ & 1,000 \\
\hline & & Sig. (2-tailed) & 0,000 & \\
\hline & & $\mathrm{N}$ & 24 & 24 \\
\hline \multicolumn{3}{|c|}{ Koperasi B } & $\begin{array}{c}\text { Karakteristik } \\
\text { Individu }\end{array}$ & $\begin{array}{l}\text { Kohesivitas } \\
\text { Kelompok }\end{array}$ \\
\hline \multirow{6}{*}{$\begin{array}{l}\text { Spearman's } \\
\text { rho }\end{array}$} & \multirow{3}{*}{$\begin{array}{l}\text { Karakteristik } \\
\text { Individu }\end{array}$} & Correlation Coefficient & 1,000 & $.672^{* * *}$ \\
\hline & & Sig. (2-tailed) & & 0,000 \\
\hline & & $\mathrm{N}$ & 26 & 26 \\
\hline & \multirow{3}{*}{$\begin{array}{l}\text { Kohesivitas } \\
\text { Kelompok }\end{array}$} & Correlation Coefficient & $.672^{* *}$ & 1,000 \\
\hline & & Sig. (2-tailed) & 0,000 & \\
\hline & & $\mathrm{N}$ & 26 & 26 \\
\hline
\end{tabular}

\begin{tabular}{c|l|l|r|r}
\hline \multicolumn{2}{c|}{ Koperasi C } & $\begin{array}{c}\text { Karakteristik } \\
\text { Individu }\end{array}$ & $\begin{array}{c}\text { Kohesivitas } \\
\text { Kelompok }\end{array}$ \\
\hline \multirow{4}{*}{$\begin{array}{c}\text { Spearman's } \\
\text { rho }\end{array}$} & $\begin{array}{c}\text { Karakteristik } \\
\text { Individu }\end{array}$ & Correlation Coefficient & 1,000 & $.463^{* *}$ \\
\cline { 2 - 6 } & Sig. (2-tailed) & & 0,006 \\
\cline { 2 - 6 } & $\begin{array}{c}\text { Kohesivitas } \\
\text { Kelompok }\end{array}$ & Correlation Coefficient & $.463^{* *}$ & 1,000 \\
\cline { 3 - 6 } & Sig. (2-tailed) & 0,006 & 34 \\
\hline
\end{tabular}

*. Correlation is significant at the 0.05 level (2-tailed).

**. Correlation is significant at the 0.01 level (2-tailed).

(Sumber: Hasil olahan peneliti, 2021)

Hasil uji korelasi seperti yang terlihat pada tabel 3, menunjukkan bahwa karakteristik individu dan kohesivitas kelompok memiliki hubungan yang signifikan dan positif dengan derajat hubungan yang berbeda pada ketiga koperasi. Pada koperasi A dan B, karakteristik individu dan kohesivitas kelompok memiliki hubungan yang tinggi dan 
kuat dengan koefisien korelasi Spearman sebesar 0,779 pada koperasi A dan 0,672 pada koperasi B dengan tingkat signifikasi pada dua level. Sementara pada koperasi C, karakteristik individu dan kohesivitas kelompok memiliki hubungan yang cukup kuat dengan koefisien korelasi Spearman sebesar 0,463 dan tingkat signifikasi pada dua level. Berdasarkan hasil uji korelasi antara karakteristik individu dan kohesivitas kelompok pada ketiga koperasi, dapat disimpulkan bahwa Ha diterima dan Ho ditolak, artinya karakteristik individu memiliki hubungan yang signifikan dan positif dengan kohesivitas kelompok pada koperasi.

Berdasarkan pembahasan hubungan antara karakteristik individu dan kohesivitas kelompok, maka dapat disimpulkan bahwa individu dalam hal ini anggota koperasi merupakan sumber daya yang terpenting dalam suatu kelompok, dimana anggotaanggota koperasi ini memberikan tenaga, ide, gagasan dan usaha kepada koperasi agar koperasi tetap hidup dan dapat mencapai tujuannnya. Setiap anggota yang tergabung dalam koperasi memiliki karakteristik individu yang menjadi ciri khas atau sifat khusus yang melekat dan menjadikannya berbeda dengan individu lain. Karakteristik yang dimiliki masing-masing individu mencerminkan kepribadian setiap anggota koperasi yang terwujud ke dalam cara individu berinteraksi dengan sesama anggota kelompok. Interaksi yang intens diantara anggota koperasi membuat mereka semakin mengenal satu sama lain, membentuk kesamaan perasaan dan pandangan yang akan mengarah pada pembentukan kohesivitas kelompok. Jika anggota tersebut bergabung dengan koperasi yang memiliki situasi yang kondusif dan kompak maka hal tersebut akan membuatnya merasa nyaman dan senang sehingga cendurung akan bertahan, demikian sebaliknya, jika anggota tidak nyaman maka dia akan memilih untuk keluar dari koperasi. Merujuk pada penelitian Faturochman, Berg dan Landreth tingginya kohesivitas kelompok berarti setiap anggota dalam kelompok memiliki komitmen yang tinggi dengan kelompoknya, interaksi di dalam kelompok didasari kerjasama bukan persaingan, kelompok mempunyai tujuan yang dikembangkan dan dirumuskan bersama, serta adanya ketertarikan antaranggota sehingga relasi yang terbentuk menguatkan jaringan relasi dalam kelompok, anggota akan lebih produktif, tidak mudah terpengaruh hal-hal negatif dari luar koperasi, serta lebih terbuka terhadap pengaruh sesama anggota kelompok, (Harmaini, 2016).

\section{PENUTUP}

Simpulan

Berdasarkan hasil penelitian dan pembahasan tentang kohesivitas kelompok pada koperasi di Kabupaten Tapanuli Utara, maka dapat disimpulkan bahwa karakteristik individu memiliki hubungan yang signifikan dengan kohesivitas kelompok dimana karakteristik individu seperti usia, pendidikan non formal, pengalaman usaha dan masa keanggotaan memiliki hubungan yang cukup kuat dengan kekuatan sosial dan daya tarik koperasi. Usia, pendidikan non formal, pengalaman usaha, masa keanggotaan dan jumlah tanggungan memiliki hubungan yang cukup kuat dengan kesatuan dalam koperasi. Usia, pendidikan non formal dan pengalaman usaha memiliki hubungan yang cukup kuat dengan kerjasama dalam koperasi.

\section{Saran}

Dinas Koperasi, Usaha Kecil dan Menengah Kabupaten Tapanuli Utara perlu mengadakan pelatihan yang melibatkan semua anggota koperasi, khususnya pelatihan terkait produksi pertanian dan teknik pertanian yang baru, karena hasil penelitian menunjukkan bahwa pendidikan non formal atau pelatihan yang diikuti oleh anggota koperasi masih minim, padahal pelatihan tersebut memiliki pengaruh yang signifikan 
terhadap kohesivitas kelompok dan kemampuan anggota dalam berkomunikasi, dimana hal tersebut akan mempengaruhi proses pencapaian tujuan koperasi.

\section{DAFTAR PUSTAKA}

Abidin, Yusuf Zainal. (2015). Metode Penelitian Komunikasi: Penelitian Kuantitatif Teori dan Aplikasi. Bandung: Pustaka Setia.

Ajija, Shochrul Rohmatul et al. (2018). Koperasi BMT: Teori, Aplikasi dan Inovasi. Jawa Tengah: Inti Media Komunika.

Alfathan, Ibnu Harits \& Saleh, Amiruddin. (2018). Gaya Kepemimpinan dan Intensitas Komunikasi GPPT dengan Efektivitas Kelompok di Sekolah Peternakan Rakyat. Jurnal Sains Komunikasi dan Pengembangan Masyarakat, 2(3), 289-300. doi:10.29244/jskpm.2.3.289-300

Bakti, Iriana et al. (2017). Hubungan antara Karakteristik Individu Petani dengan Kohesivitas Kelompok Tani Tanaman Obat. Jurnal Ilmiah Ilmu Hubungan Masyarakat, 1(2), 153-163. doi: https://doi.org/10.24198/prh.v1i2.10294

BPS. (2020). Profil Kemiskinan di Indonesia Maret 2020 No. 56/07/Th. XXIII. 15 Juli 2020

Bungin, Burhan. (2014). Metode Penelitian Kuantitatif: Komunikasi, Ekonomi dan Kebijakan Publik serta Ilmu-Ilmu Sosial Lainnya. Jakarta: Kencana Prenada Media Group.

Cindoswari, Ageng Rara \& Junep, Annisa Risecha. (2017). Pola Komunikasi dan Gaya Kepemimpinan dengan Kohesivitas Kelompok Paguyuban. Jurnal Komunikasi dan Media, 1(2), 98-120.

Damanik, Inta P.N. (2013). Faktor-faktor yang Mempengaruhi Dinamika Kelompok dan Hubungannya dengan Kelas Kemampuan Kelompok Tani di Desa Pulokencana Kabupaten Serang. Jurnal Penyuluhan, 9(1), 31-40. doi:10.25015/penyuluhan.v9i1.9856

Fadillah, Muhammad R. \& Riyanto, Sutisna. (2019). Analisis Efektivitas Kelompok dalam Sekolah Peternakan Rakyat. Jurnal Sains Komunikasi dan Pengembangan Masyarakat, 4(1), 87-98. doi: 10.29244/jskpm.4.1.87-98

Gurning, Fina Pratini et al. (2012). Komunikasi Kelompok pada Komunitas Kompas MuDA. Jurnal Mahasiswa Universitas Padjadjaran, 1(1), 1-15.

Littlejohn, Stephen W. \& Foss, Karen A. (2011). Teori Komunikasi, edisi 9. Jakarta: Salemba Humanika.

Morissan. (2020). Komunikasi Organisasi. Jakarta: Prenadamedia Group.

Morisson, Rachel. (2007). Enemies At Work. Research paper series Auckland University of Technology. paper 32-2007.

Rahmawati, Alfi. (2016). Analisis Jaringan Komunikasi dalam Diseminasi Informasi Produksi dan Pemasaran Jeruk Pamelo. Tesis Magister Komunikasi Pembangunan Pertanian dan Pedesaan, Sekolah Pascasarjana, Institut Pertanian Bogor.

Rakhmat, Jalaluddin. (2018). Psikologi Komunikasi. Bandung: Simbiosa Rekatama Media.

Rasyid, Erwin et al. (2019). Jaringan komunikasi dalam pengelolaan perencanaan program penanggulangan kemiskinan di Provinsi Sulawesi Barat. Jurnal Kajian Komunikasi, 7(2), 133-144. doi: 10.24198/jkk.v7i2.19574

Sidabutar, Windo Harjoin. (2020). Analisis Jaringan Komunikasi pada Efektivitas Komunikasi, Informasi dan Edukasi (KIE) Mengenai Alat/Metode Kontrasepsi di Kampung Keluarga Berencana (KB) Kelurahan Gaharu, Kota Medan. Tesis Magister Ilmu Komunikasi, Fakultas Ilmu Sosial dan Ilmu Politik, Universitas Sumatera Utara. 
Sinaga, Febri Adi et al. (2016). Analisis Dinamika Kelompoktani Sagu di Desa Lukun Kecamatan Tebing Tinggi Timur Kabupaten Kepulauan Meranti. Jurnal Jom Faperta UR, 3(2), 1-6.

Situmeang, Ilona V.Oisina. (2016). Komunikasi Organisasi dalam Perspektif Objektif dan Perspektif Subjektif. Yogyakarta: Ekuilibria.

Sitepu, Anwar. (2016). Analisis Efektifitas Kelompok Usaha Bersama sebagai Instrumen Program Penanganan Fakir Miskin. Jurnal Sosio Informa, 2(1), 53-68. doi: 10.33007/inf.v2i1.212

Sukidjo. (2008). Membangun Citra Koperasi Indonesia. Jurnal Ekonomi \& Pendidikan, 5(2), 193-203.

Sulistiawati, Asri. (2018). Analisis Jaringan Komunikasi Tingkat Kelompok dalam Gapoktan. Jurnal Sains Komunikasi dan Pengembangan Masyarakat, 2(2), 155168.

Supit, Veky et al. (2016). Kajian Dinamika Kelompok Tani Dalam Peningkatan Pendapatan Kecamatan Tomohon Timur Kota Tomohon. Jurnal Ilmu Sosial \& Pengelolaan Sumberdaya Pembangunan, 3, 103-113.

Syahroni, Iqbal \& Amanah, Siti. (2018). Hubungan Antara Gaya Kepemimpinan Ketua dan Efektivitas Kelompok Wanita Tani Toga. Jurnal Sains Komunikasi dan Pengembangan Masyarakat, 2(4), 441-454. doi: 10.29244/jskpm.2.4.441-454

Toseland RW et al. (2015). Group Dynamics. New York (US): Guilford Publication. Undang-Undang Republik Indonesia Nomor 17 Tahun 2012 tentang Perkoperasian

Utami, Shelly Saraswati. (2017). Hubungan Komunikasi Interpersonal Terhadap Kohesivitas Kelompok Pada Event Organizer. Skripsi Psikologi, Fakultas Ilmu Sosial dan Ilmu Politik,, Universitas Brawijaya.

Wahyuni, Sri et al. (2017). Hubungan Jaringan Komunikasi dan Dinamika Kelompok dengan Kapasitas Petani dalam Agribisnis Padi Organik di Jawa Barat. Jurnal Penyuluhan, 13(1), 110-120. doi: 10.25015/penyuluhan.v13i1.15115

Walgito, Bimo. (2003). Psikologi Sosial. Yogyakarta: Andi Offset. 